\title{
Comparing Retirement Wealth Trajectories on Both Sides of the Pond
}

Richard Blundell, Rowena Crawford, Eric French, and Gemma Tetlow 


\title{
Comparing Retirement Wealth Trajectories on Both Sides of the Pond
}

\author{
Richard Blundell \\ University College London and Institute for Fiscal Studies \\ Rowena Crawford \\ Institute for Fiscal Studies \\ Eric French \\ University College London and Institute for Fiscal Studies \\ Gemma Tetlow \\ University College London and Institute for Fiscal Studies
}

September 2015

\author{
Michigan Retirement Research Center \\ University of Michigan \\ P.O. Box 1248 \\ Ann Arbor, MI 48104 \\ www.mrrc.isr.umich.edu \\ (734) 615-0422
}

\section{Acknowledgements}

The research reported herein was performed pursuant to a grant from the U.S. Social Security Administration (SSA) funded as part of the Retirement Research Consortium through the University of Michigan Retirement Research Center (5 RRC08098401-07). The opinions and conclusions expressed are solely those of the author(s) and do not represent the opinions or policy of SSA or any agency of the Federal Government. Neither the United States Government or any agency thereof, or any of their employees, makes any warranty, express or implied, or assumes any legal liability or responsibility for the accuracy, completeness, or usefulness of the contents of this report. Reference herein to any specific commercial product, process or service by trade name, trademark, manufacturer, or otherwise does not necessarily constitute or imply endorsement, recommendation or favoring by the United States Government or any agency thereof. 


\title{
Comparing Retirement Wealth Trajectories on Both Sides of the Pond
}

\begin{abstract}
We use comparable data from the U.S. and England to examine similarities and differences in the level and trajectories of assets among households age 70 and older. We find that in the U.S. assets, on average, decline gradually with age, while in England, older households actually accumulate wealth. These differences appear to be driven largely, though not entirely, by housing wealth: During the period we consider, house price growth drove increases in housing wealth in England that more than offset the slow drawdown of nonhousing wealth. This suggests the illiquid nature of housing is likely to be an important factor in explaining wealth drawdown at older ages. We also consider the potential importance of bequest motives and savings to insure against the risk of medical and long-term care expenses.
\end{abstract}

\section{Citation}

Blundell, Richard, Rowena Crawford, Eric French, and Gemma Tetlow. 2015. "Comparing Retirement Wealth Trajectories on Both Sides of the Pond.” University of Michigan Retirement Research Center (MRRC) Working Paper, WP 2015-333. Ann Arbor, MI. http://www.mrrc.isr.umich.edu/publications/papers/pdf/wp333.pdf

\section{Authors' acknowledgements}

We thank Thomas Crossley, Mariacristina De Nardi, John Jones, and an anonymous referee for comments. We gratefully acknowledge financial support from the Social Security Administration through the Michigan Retirement Research Center. The views expressed in this paper are those of the authors and not necessarily those of the Social Security Administration or the MRRC. 


\section{Introduction}

Many households hold substantial assets throughout retirement and until death. This fact has been documented in many countries, and is in contrast to the simplest version life-cycle model. Many explanations and permutations to the life-cycle model have been proposed to explain this - for example, bequest motives (De Nardi (2004), Love et al. (2009)), precautionary saving for health expenses (Love et al. (2009), De Nardi et al. (2010), Kopecky and Koreshkova (2014)), and people's inability or lack of desire to run down their housing wealth during retirement (Yang (2009), Nakajima and Telyukova (2012)). However, the existing literature has not yet reached a consensus on the relative importance of different explanations. See De Nardi et al. (2015) for a recent survey.

This remains an important public policy issue in many countries. The retention of wealth observed among older households stands in apparent contrast to popular concerns over the inadequate retirement wealth accumulation of younger households. Furthermore, the elderly typically hold a large share of national wealth: more than one-third of total wealth in the United States is held by households whose heads are older than age 65 (Wolf (2004)). Understanding the motivations behind household saving behavior is therefore crucial for deciding whether policy action to influence household behavior is warranted and, if it is, what form it would best take. For example, if older households hold large amounts of wealth due to bequest motives, then changes in inheritance taxation may significantly affect savings behaviour. Alternatively, if households hold large amounts of wealth because their wealth is illiquid (in housing wealth, for example), then the inheritance tax likely has only a small effect on savings behavior. Furthermore, policy action to improve liquidity or influence households' asset choices may improve welfare.

In this paper we use comparable data for the U.S. and England, drawn from the Health and Retirement Study and the English Longitudinal Study of Ageing, to examine the similarities and differences in the level and trajectory of assets among households in retirement. Both countries share a common language and heritage, but have different institutions and different asset returns, which therefore provide different incentives for households to accumulate and decumulate wealth. Comparing patterns across the two countries therefore helps U.S. to identify what is potentially driving wealth dynamics.

We show that life expectancies, median income, and asset levels at age 70-74 were similar in the U.S. and England in 2002, suggesting that resources of those recently retired are similar across the two countries. However, real incomes tend to rise throughout later life in England but fall in the US, meaning that for those near the median, retirement income in England is larger than in the United States. Since retirement income is greater in England, the simple life-cycle model would suggest English households have less need to save and should thus decumulate wealth faster than their U.S. counterparts. This conclusion would likely be strengthened further if we built in other explanations 
that have been put forward for why U.S. households decumulate wealth so slowly at older ages. For example, English households have lower out-of-pocket medical spending late in life and thus need to save less for this than their American counterparts, again allowing them to have lower assets late in life. However, we show that over the period 2002-2011 assets were drawn down more slowly in England than the US. In fact, median net wealth of older English households actually increased over the period.

This striking difference is largely attributable to the more rapid growth in house prices in England over the period. However, notwithstanding the question of why households did not draw on this positive wealth shock, there are other differences as well: Nonhousing wealth was decumulated less rapidly in England, and even stripping out house price changes, housing wealth was drawn on less in England than the U.S.

These comparisons suggest that the nature of housing as an asset - its utility value, illiquidity, and mix of risk and returns - is likely to be an important factor in explaining the trajectory of wealth in retirement. This is in line with the findings of Nakajima and Telyukova $(2013,2014)$, and contrary to the findings of Skinner (1996). In this analysis, we do not quantify the relative importance of housing versus other factors driving retirement savings, such as bequest motives or saving to insure against the risk of living long and having high medical spending. Disentangling the relative importance of these factors is an interesting direction for future research.

This paper proceeds as follows. In the next section, we discuss the essential features of the data used. In section III, we present our key empirical comparisons of the level and trajectory of wealth in England and the U.S. In section IV, we discuss some of the possible explanations for the differences observed, including bequest motives, health expense risk and the role of housing. Finally, section V highlights our main conclusions and points to important directions for future work.

\section{Data}

An attractive feature of our cross-country comparison is that we are able to exploit comparable panel data for the U.S. and England. For the U.S. our data are drawn from the Health and Retirement Study (HRS). For England our data are drawn from the English Longitudinal Study of Ageing (ELSA). These are both biennial panel surveys of the private household population age 50 and older, that collect detailed information on income, wealth, demographic and socioeconomic circumstances and health.

ELSA has been conducted biennially since 2002/3, and we use five waves of data (specifically:

2002/3, 2004/5, 2006/7, 2008/9, and 2010/11). The HRS has been running since 1992, but we restrict our attention to the five waves of data from 2002 onwards for comparability with ELSA (specifically: 2002, 2004, 2006, 2008, and 2010). 
ELSA was designed to be comparable to the HRS, and so the timing and structure of the surveys, the measures of assets and income collected, and the methods used to collect the relevant information are similar. For example, both surveys employ the method of 'unfolding brackets' if a respondent is unable to give a point estimate for the value of a particular asset. This gives U.S. confidence that the differences in wealth that we observe between the U.S. and England represent genuine cross-country differences rather than being artifacts of sample or survey design.

HRS and ELSA both suffer from (nonrandom) attrition. However, in both surveys deaths are verified using administrative data (the National Death Index in the U.S. and the National Health Service Central Register in England). This enables U.S. to distinguish between deaths and attrition for reasons other than death, and even to identify deaths among those who have previously attrited from the survey.

\section{Sample selection}

We focus our analysis on households age 70 and older when observed in 2002, in order to abstract from the retirement decision and its impact on the level and profile of household assets. For the same reason we exclude from the sample those who report earning $\$ 3,000$ per year or more $(£ 1,765)$. We also exclude from the sample households who divorce, separate, or get married after 2002 (since such changes in family structure may alter household wealth in a way that is unrelated to normal accumulation or decumulation behaviour), cohabiting households (since HRS does not collect all the necessary financial information from both individuals), and households where one or more members is in an institution (due to concerns over the quality of their financial information). The resulting sample consists of 5,139 U.S. households and 2,458 English households. Of these, 2,441 U.S. households and 968 English households have at least one member who survives the eight years that our panel data cover.

\section{Measurement of assets and income in ELSA and HRS}

ELSA and the HRS both collect the self-reported value of many different types of assets. The assets we include in our measure of total net wealth are described in Table 1. In addition to the assets described, the HRS also collects data on vehicle wealth owned by U.S. households. We do not include this in our measure of wealth, not least because equivalent information is not collected for English households. 
TABLE 1

Definitions of wealth

\begin{tabular}{|c|c|c|}
\hline & US & England \\
\hline \multicolumn{3}{|l|}{ Net assets: } \\
\hline \multicolumn{3}{|l|}{ Net primary housing } \\
\hline Primary Housing & Value of primary residence & Value of primary residence \\
\hline $\begin{array}{l}\text { Less primary } \\
\text { housing debts }\end{array}$ & $\begin{array}{l}\text { Value of all mortgages, } \\
\text { land contracts and other } \\
\text { home loans on primary } \\
\text { residence }\end{array}$ & $\begin{array}{l}\text { Value of all mortgages on } \\
\text { primary residence }\end{array}$ \\
\hline \multicolumn{3}{|l|}{ Net nonhousing } \\
\hline Liquid assets & $\begin{array}{l}\text { Value of CDs, government } \\
\text { savings bonds and T-bills }\end{array}$ & $\begin{array}{l}\text { Value of current and savings } \\
\text { accounts, cash ISAs, } \\
\text { TESSAs and National } \\
\text { Savings products }\end{array}$ \\
\hline Stocks & $\begin{array}{l}\text { Net value of stocks, mutual } \\
\text { funds and investments }\end{array}$ & $\begin{array}{l}\text { Shares, investment ISAs, } \\
\text { PEPs }\end{array}$ \\
\hline Bonds & $\begin{array}{l}\text { Net value of bonds and } \\
\text { bond funds }\end{array}$ & Bonds, premium bonds \\
\hline Other assets & $\begin{array}{l}\text { Net value of all other } \\
\text { savings or assets (e.g. } \\
\text { jewelry, money owed by } \\
\text { others, collections, rights in } \\
\text { a trust or estate) }\end{array}$ & $\begin{array}{l}\text { Physical assets (land, } \\
\text { antiques, trusts) }\end{array}$ \\
\hline Other property & $\begin{array}{l}\text { Net value of real estate (not } \\
\text { primary residence) }\end{array}$ & Second homes \\
\hline Business assets & $\begin{array}{l}\text { Net value of business or } \\
\text { farm assets }\end{array}$ & $\begin{array}{l}\text { Business wealth, farm and } \\
\text { business property }\end{array}$ \\
\hline Pension assets & $\begin{array}{l}\text { Net value of IRA and } \\
\text { Keogh accounts }\end{array}$ & None* \\
\hline Less debts & $\begin{array}{l}\text { Other debts (e.g. credit card } \\
\text { balances, medical debts, } \\
\text { life insurance policy loans, } \\
\text { loans from relatives) }\end{array}$ & $\begin{array}{l}\text { Financial debt (credit cards, } \\
\text { private debt, loans, mail } \\
\text { order }\end{array}$ \\
\hline
\end{tabular}

Notes: *In England (during the period in question) it was essentially mandatory to purchase an annuity with any defined contribution pension wealth before the age of 75. Pension assets are therefore negligible among our sample of English households (less than 1percent of individuals aged 70-74 held unannuitized pension wealth, and the ELSA survey did not elicit the value of these assets).

The only important difference between the assets included in wealth in the two countries is with respect to pension wealth. In England (during the period in question) it was essentially mandatory to purchase an annuity with any defined contribution pension wealth before the age of 75 . Pension assets are therefore negligible among our sample of English households, while U.S. households can (and do) hold large amounts of pension wealth in Individual Retirement Accounts (IRAs) and Keogh accounts that they can access relatively flexibly.

ELSA and the HRS both collect the self-reported level of income from a number of different sources, but one important difference is that ELSA generally collects income net of tax, while the HRS collects income gross of tax. We calculate net income for HRS households following the 
methodology of Rohwedder et al (2005), making use of the NBER tax calculator "TAXSIM". ${ }^{1}$ Since we only observe the census division each household resides in and not their state, we approximate households' state income tax liabilities using a population weighted average of the liabilities across the states that make up the household's census division of residence.

All figures are converted into real terms and expressed in 2014 prices. For the U.S., we use the Personal Consumption Expenditures (PCE) price index. For England, we use the Implied Price Deflator, since this is the price index that is most similar to the PCE. For ease of comparison. all figures are expressed in U.S. dollars. We convert from British pounds to U.S. dollars using an exchange rate of $\$ 1.7$ per pound, which is the average exchange rate over the period 2002-2010.

\section{Empirical facts on asset decumulation}

\section{Wealth at the start of retirement}

To provide context for our comparison of asset trajectories over time, we start by describing the distribution and composition of household wealth for those toward the start of retirement. Figure 1 shows the distribution of total net wealth in England and the U.S. for households ages 70-74 in 2002. Median wealth is remarkably similar in the two countries, at \$228,164 in England and \$221,295 in the U.S. However, the distribution of wealth is much more positively skewed in the U.S.: The $75^{\text {th }}$ percentile of the wealth distribution in England is \$453,773 and the mean $\$ 341,807$, compared to $\$ 573,122$ and $\$ 538,371$ respectively in the US. At the other end, the wealth distribution is more similar. In the U.S., seven percent of households have zero or negative net wealth, while in England that figure is four percent.

\footnotetext{
${ }^{1}$ See http://www.nber.org/taxsim/ and Freenberg, D.R. and Coutts, E. (1993) for more information.
} 


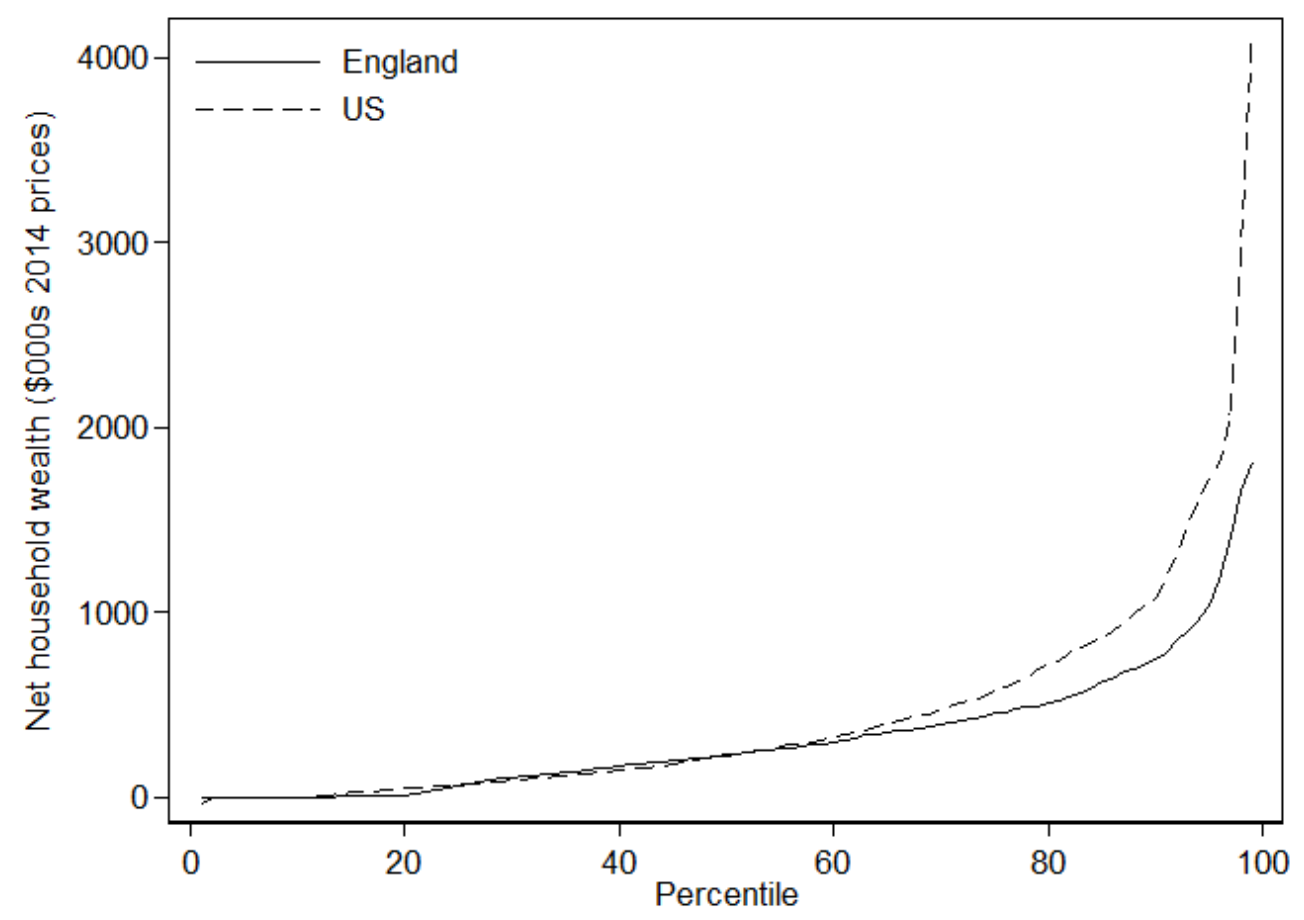

Table 2 describes the composition of wealth for the same households. Table 2 shows the share of all households with positive values for different asset types, as well as each asset type's share of total wealth for our sample, first for the U.S. then England. In both countries, most households own a home: 79.4 percent and 73.7 percent of U.S., and English households hold gross property wealth, respectively. However, there is a striking difference in the share of wealth held in housing across the two countries. In the U.S., gross primary housing wealth accounts for about one-third of gross wealth, while in England it accounts for two-thirds. Mean housing wealth among English households ages 70-74 in 2002 was \$225,410, compared to \$167,084 among U.S. households. In other words, despite mean total wealth being higher in the U.S. than in England, mean housing wealth is actually higher in England than in the U.S. (the only asset type for which this is the case). Housing related debts are also much less prevalent at older ages in England: Only five percent of households reported having any housing debt (mortgages or equity withdrawal arrangements), compared to more than 20 percent of households in the U.S. It is clear from these observations that housing wealth will have an important role in the evolution of total wealth at older ages, particularly for English households. 
TABLE 2

Composition of wealth holdings in 2002, households aged 70-74

\begin{tabular}{|l|c|c|c|c|c|c|}
\hline & \multicolumn{3}{|c|}{ US } & \multicolumn{3}{c|}{ England } \\
\hline & Prevalence & Mean & $\begin{array}{c}\text { percent } \\
\text { gross } \\
\text { assets }\end{array}$ & Prevalence & Mean & $\begin{array}{c}\text { percent } \\
\text { gross } \\
\text { assets }\end{array}$ \\
\hline Gross assets & $93.2 \%$ & 538,371 & & $97.5 \%$ & 341,807 & \\
\hline Liquid assets & $86.3 \%$ & 59,420 & $11.0 \%$ & $94.4 \%$ & 45,268 & $13.2 \%$ \\
\hline Stocks & $33.0 \%$ & 79,145 & $14.7 \%$ & $37.3 \%$ & 21,068 & $6.2 \%$ \\
\hline Bonds & $10.2 \%$ & 13,670 & $2.5 \%$ & $39.8 \%$ & 8,799 & $2.6 \%$ \\
\hline Other assets & $10.7 \%$ & 10,947 & $2.0 \%$ & $6.3 \%$ & 5,726 & $1.7 \%$ \\
\hline Primary housing & $80.7 \%$ & 167,084 & $31.0 \%$ & $73.9 \%$ & 225,410 & $65.9 \%$ \\
\hline Other property & $17.0 \%$ & 96,867 & $18.0 \%$ & $9.9 \%$ & 23,166 & $6.8 \%$ \\
\hline Business assets & $7.2 \%$ & 30,128 & $5.6 \%$ & $3.1 \%$ & 12,372 & $3.6 \%$ \\
\hline Pension assets & $44.2 \%$ & 81,109 & $15.1 \%$ & $0.0 \%$ & 0 & $0.0 \%$ \\
\hline Less mortgage debts & $20.2 \%$ & 14,286 & $2.7 \%$ & $6.0 \%$ & 2,705 & $0.8 \%$ \\
\hline Less other debts & $17.4 \%$ & 1,673 & $0.3 \%$ & $17.3 \%$ & 974 & $0.3 \%$ \\
\hline Net assets & $90.0 \%$ & 522,413 & $97.0 \%$ & $95.7 \%$ & 338,129 & $98.9 \%$ \\
\hline
\end{tabular}

There are other interesting differences in the types of assets that U.S. and English households hold. English households are more likely to hold bonds than their U.S. counterparts, likely explained by the prevalence of 'premium bonds' in England. However, the bonds held by English households are usually small in value. Thus the share of bonds in total wealth is similar across the two countries. English households are also slightly more likely to hold stocks, but again many of these holdings are small and thus stocks account for a smaller share of all wealth held by the elderly in England than in the U.S. The English are less likely to hold property wealth outside the main residence or business assets. English households at these ages also do not typically hold unannuitized pension wealth, in contrast to U.S. households who did not face the same legal compulsion to annuitize accumulated pension wealth by age 75 .

\section{Factors affecting wealth decumulation}

Even though many U.S. and English households have similar levels of wealth at ages 70-74, a simple life-cycle model would not necessarily predict the same asset trajectories for the two countries. Leaving aside the issue of potentially different preferences, the path of assets throughout later life would depend on life expectancies and the level and path of household income, which could differ between the countries. In more sophisticated life-cycle models, other factors will also come to bear, such as differences in medical (or other) expense risk. We will return to a discussion of the potential drivers of different asset trajectories in Section 4, but it is useful, before presenting our empirical results, to fix ideas on the differences (or lack thereof) between the U.S. and England in terms of the inputs into the simplest life-cycle models. 


\section{a) Life expectancies}

Life expectancies, conditional on reaching ages 70-74, are similar in the U.S. and England. The interested reader is directed to Crimmins et al. (2011) for a comprehensive discussion of differences in longevity across countries and how these have changed over time. Table 3 describes average life expectancies by age and sex, drawn from the period life tables compiled by the Human Mortality Database. For example, U.S. men ages $70-74$ in 2000-09 could, on average, expect to live another 13.5 years, and U.S. women another 15.9 years, compared to 13.2 years for English men and 15.7 years for English women. Differences between the countries at older ages are similar.

This indicates that asset trajectories would not be expected to differ because of differences in life expectancies. Household savings behaviour is, of course, driven by households' own expectations of life, and so different perceptions of life expectancy could potentially have a role.

TABLE 3

Life expectancies, 2000-2009

\begin{tabular}{|l|c|c|c|c|c|c|}
\hline & \multicolumn{3}{|c|}{ US } & \multicolumn{3}{c|}{ England and Wales } \\
\hline Age & Men & Women & All & Men & Women & All \\
\hline $70-74$ & 13.5 & 15.9 & 14.9 & 13.2 & 15.7 & 14.6 \\
\hline $75-79$ & 10.5 & 12.4 & 11.6 & 10.1 & 12.1 & 11.3 \\
\hline $80-84$ & 7.8 & 9.3 & 8.7 & 7.4 & 9.0 & 8.4 \\
\hline $85-89$ & 5.6 & 6.6 & 6.3 & 5.3 & 6.4 & 6.0 \\
\hline $90-94$ & 3.9 & 4.6 & 4.4 & 3.7 & 4.4 & 4.2 \\
\hline $95-99$ & 2.8 & 3.2 & 3.0 & 2.6 & 3.0 & 3.0 \\
\hline $100-104$ & 2.0 & 2.3 & 2.2 & 2.0 & 2.2 & 2.1 \\
\hline $105-109$ & 1.6 & 1.7 & 1.7 & 1.6 & 1.6 & 1.6 \\
\hline $110+$ & 1.4 & 1.4 & 1.4 & 1.3 & 1.4 & 1.4 \\
\hline
\end{tabular}

Source: Human Mortality Database

\section{b) Income}

The median level of household net income (excluding labour income and capital income) among our sample of households in 2002 is slightly lower in England than the U.S., but this difference is small. Among those ages 70-74 in 2002 median net income was around \$26,200 in the U.S. and around $\$ 24,700$ in England. The composition of this income is also remarkably similar. In the U.S. 53 percent of the noncapital, nonlabour income among this group was accounted for by social security retirement benefits (excluding those received due to disability) and 38 percent from private pensions and annuities; in England these proportions were 54 percent and 40 percent.

However, the trajectories of income over time do differ. Figure 2 shows the age profiles of household net nonlabour, noncapital income for our sample of U.S. and English households, divided into four five-year birth cohorts (those born in 1929-33, 1924-28, 1919-23, and 1914-18). In the U.S., median household income declines with age, while in England, if anything, median household income increases with age. This is likely due to institutional differences in the indexation arrangements for pension income between the two countries. In the U.S., Social Security income is price indexed in retirement, as are most employer pensions. In England, the basic state pension and other means-tested 
pensioner benefits increased faster than prices over this period, and many employer pensions are indexed above consumer price inflation.

The different trajectory of incomes would, all else equal, have implications for the path of assets in retirement. Specifically, in the U.S. where incomes decline in real terms with age, households would be expected to decumulate their assets less quickly, in order to be able to draw on these assets in later life to compensate for their falling real incomes.

FIGURE 2

Age profiles of income in the U.S. and England, by cohort 2002-2010

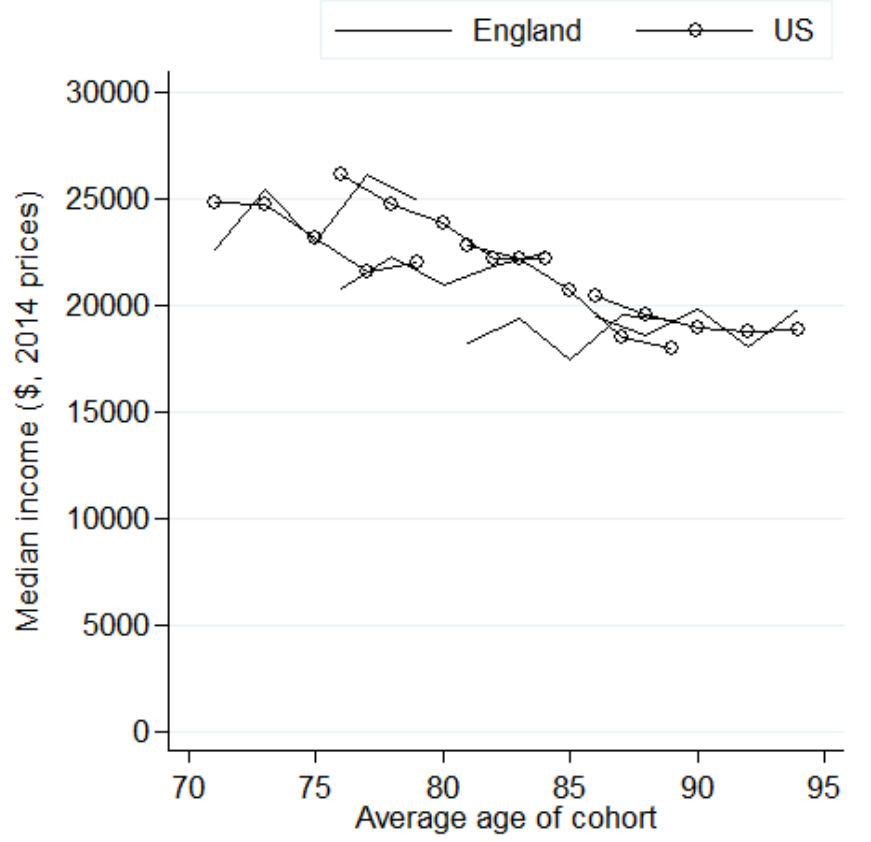

Notes: Income excludes income from assets. Sample is households observed in both 2002 and 2010.

\section{Asset trajectories at older ages}

We turn now to our empirical comparison of the trajectories of assets at older ages between the U.S. and England. Figure 3 describes for each country the age profiles of median net assets among our households, divided into four five-year birth cohorts (those born in 1929-33, 1924-28, 1919-23, and 1914-18). For the U.S., a pattern of broadly declining household wealth with age is found within cohorts. However, the same is not true of England, where we observe significant increases in wealth for each of the cohorts. 
FIGURE 3

Age profiles of total net wealth in the US and England, by cohort 2002-2010

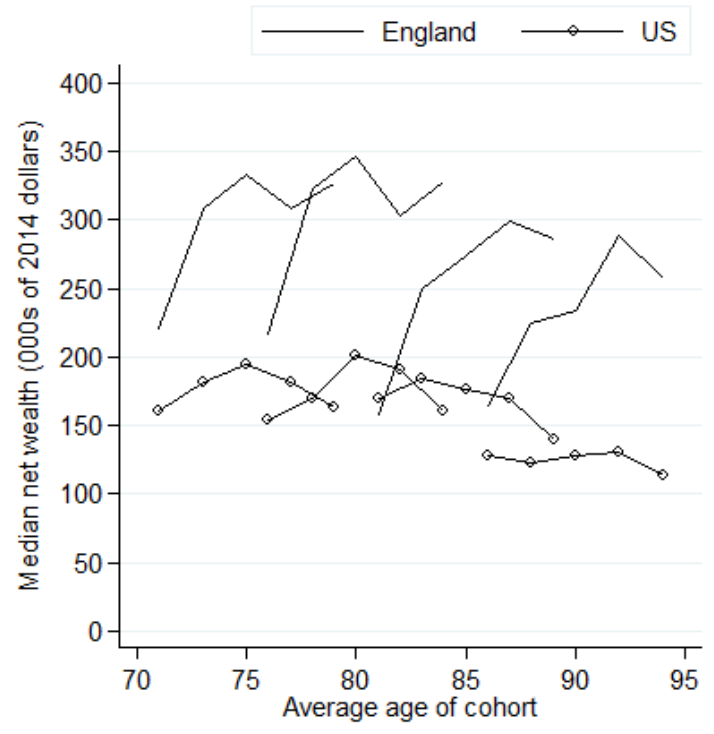

Figure 3 illustrates average wealth across all households observed in a given wave of data, even if they subsequently died or otherwise attrited from the sample. Restricting the analysis to households who had at least one member alive and responding in the final wave (we refer to this as the 'balanced' panel) increases average wealth in earlier waves in both England and the U.S. This is shown in Figure 4. This confirms that households that died or attrited from our sample tended to have lower wealth than survivors. It shows that there is more evidence that assets fall with age when tracking the same households over time. Nevertheless, whether we track everyone or the balanced panel, the key observation from Figure 3 still holds: Over this period wealth rose with age among older households in England, whereas, if anything, in the U.S. it fell. 
FIGURE 4

Age profiles of total net wealth in the US and England, comparing the balanced and unbalanced samples
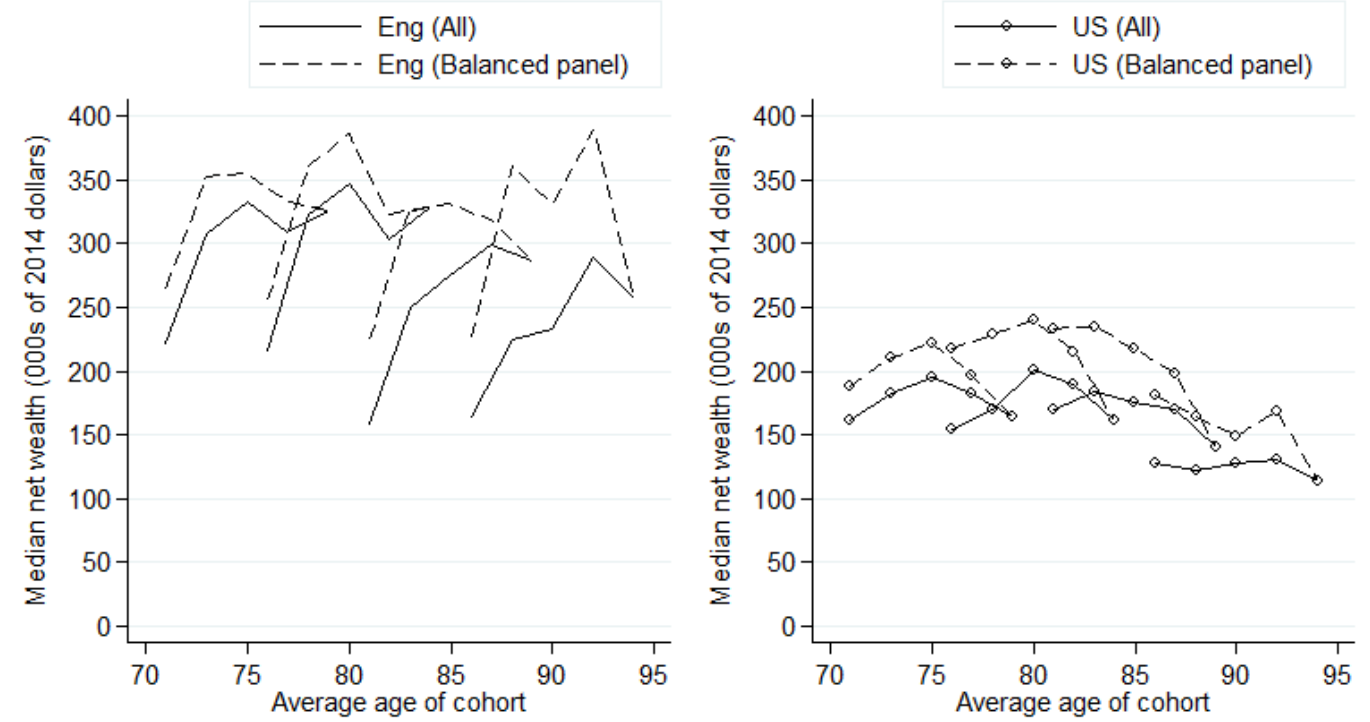

Notes: The 'balanced' sample includes only households where at least one member was still alive and responding to ELSA/HRS at the end of our panel in 2010/11.

Wealth also potentially falls on the death of a spouse, either as a result of direct costs associated with the end of life (such as medical or funeral expenses) or due to bequests made outside the household (see French, et al. (2006) for an analysis of this in the U.S.). However, restricting the sample to completely surviving households within the balanced panel makes only a minor difference to the observed profiles for net assets (not illustrated in the interests of space, but available from the authors on request). Differences in rates of death, or declines in household wealth associated with death, are therefore not driving the differences in the asset profiles observed between the U.S. and England.

As noted previously, income grows more rapidly with age in England than in the U.S. To better assess how differences in income trajectories across the two countries affect household resources in the two countries, we calculate, for each household, the present discounted value of lifetime income, then add this to the wealth measure shown in Figure 4. To calculate the present discounted value of income, we estimate age and household-structure (e.g., married, single man, single woman), specific income growth rates for both the U.S. and England. Thus we can capture the more rapid income growth for English households. Using information on observed income and estimated income growth rates to predict income in the future, we create predicted income at each age for each household in each country. Using the predicted trajectory of income, along with country specific mortality probabilities and an interest rate of three percent, we create the present discounted value of income for each household in our sample. Figure 5 shows the sum of wealth plus the present discounted income for the sample of households where at least one member survived to the end. It shows that this 
measure of resources does decline with age in both countries, since the present discounted value of future income declines with age. However, whereas this measure of wealth declines rapidly in the U.S., it declines slowly in England. Wealth falls much more rapidly with age in the U.S., even when considering a broader measure of wealth that includes future income.

FIGURE 5

Age profiles of total net wealth including the present discounted value of future non-labour income - balanced sample

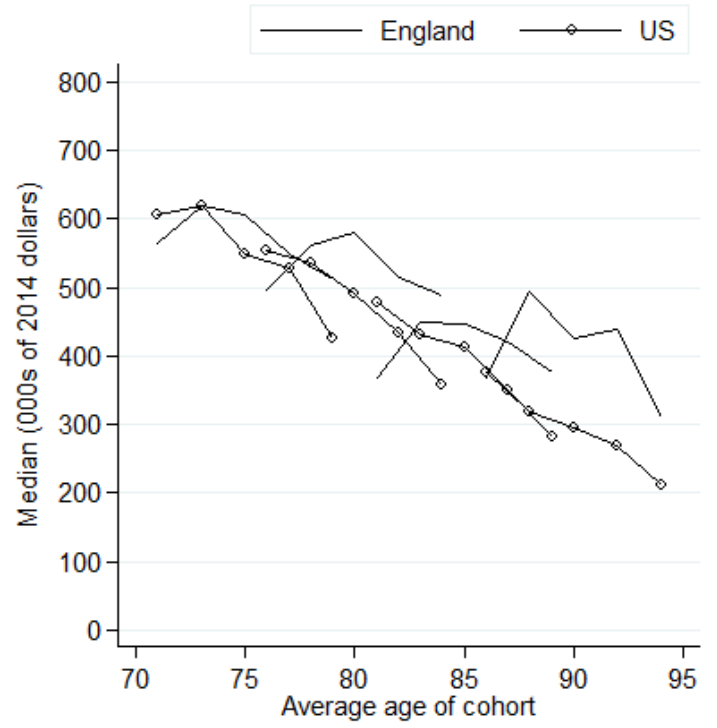

Notes: The 'balanced' sample includes only households where at least one member was still alive and responding to ELSA/HRS at the end of our panel in 2010/11. 
Figure 6 shows the age-profiles of net primary housing wealth (left panel) and net other wealth (right panel) for the balanced panel. The left panel shows that the sharp increase in median wealth in England is driven by increases in net housing wealth. This has a considerable impact on the profile of total net wealth in England because of the importance of primary housing in the household portfolio.

FIGURE 6

Age profiles of net housing wealth and net non-housing wealth - balanced sample
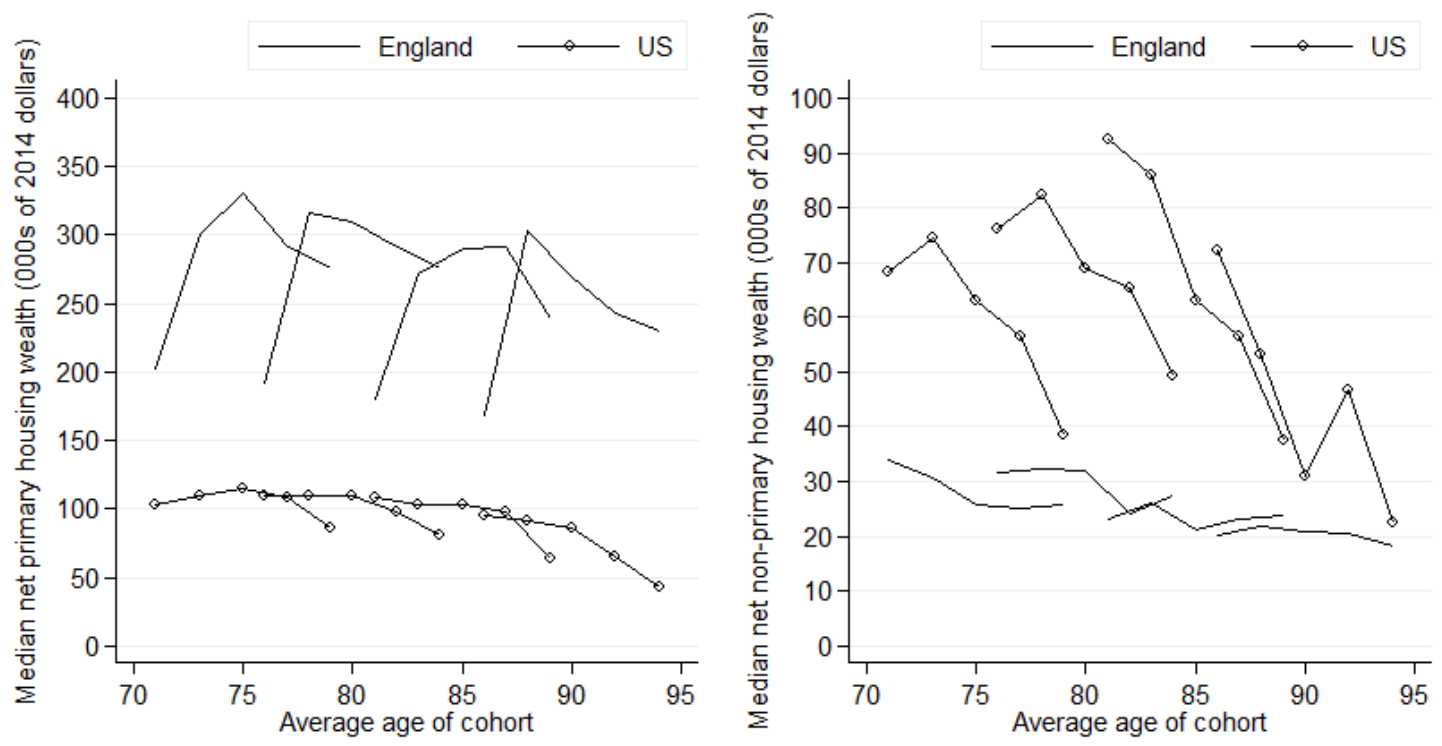

Notes: The 'balanced' sample includes only households where at least one member was still alive and responding to ELSA/HRS at the end of our panel in 2010/11.

The increase in housing wealth in England is the result of house price growth over this period, shown in Figure 7. Between 2002 and 2005, average real house prices increased by around 50 percent in England, compared to around 20 percent in the U.S. In Figure 8 we give a sense of how asset profiles may have looked in the absence of the direct impact real house-price changes (in other words, adjusting for the mechanical effect of house-price changes on household wealth, but not accounting for any behavioural change coming from home repairs or sales that might result from such different asset prices). To construct adjusted housing wealth in 2004, we take reported housing wealth of each household in that year, and scale this down according to the percentage growth in average nationwide real house prices in England or the U.S. (as applicable) between 2002 and 2004. Similarly, to construct adjusted housing wealth in 2006, we take reported housing wealth in 2006, and scale that down according to the percentage growth in average real house prices between 2002 and 2006, and so on. This is one way of illustrating what housing wealth in each year might have been had there been no change in real house prices between 2002 and that year. Adjusting for house price changes in this way suggests that - absent these effects - net property wealth would be broadly flat by age in England and slightly declining in the U.S. 
FIGURE 7

Real house price movements

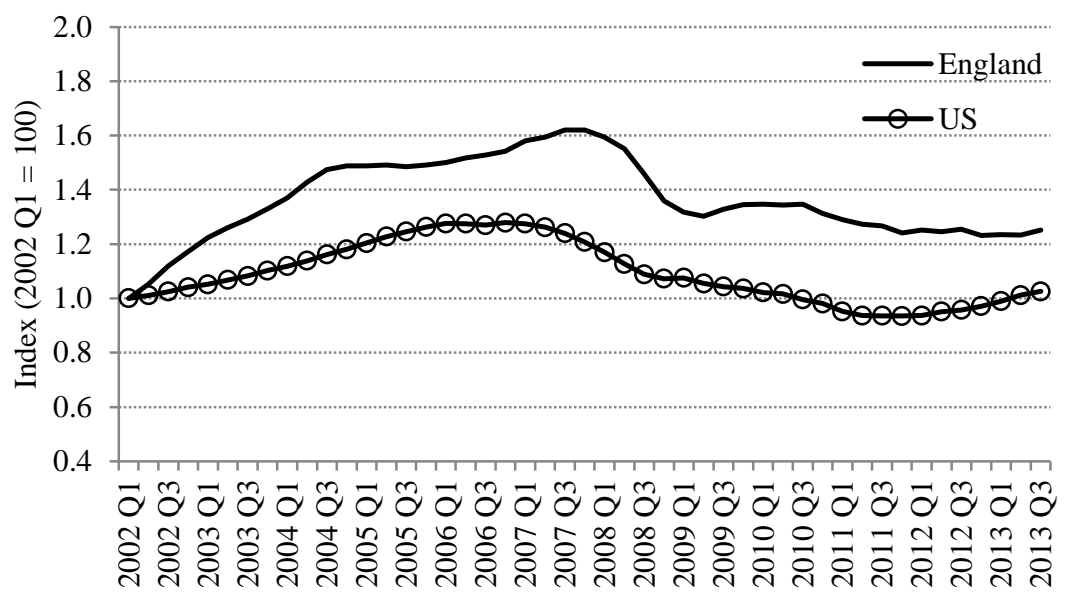

Notes: English house price data is taken from the Land Registry, converted into real terms using the IPD. U.S. house price data are taken from the S\&P/Case-Shiller Index, converted into real terms using the PCE.

\section{FIGURE 8}

Age profiles of net housing wealth adjusted for real house price increases- balanced sample

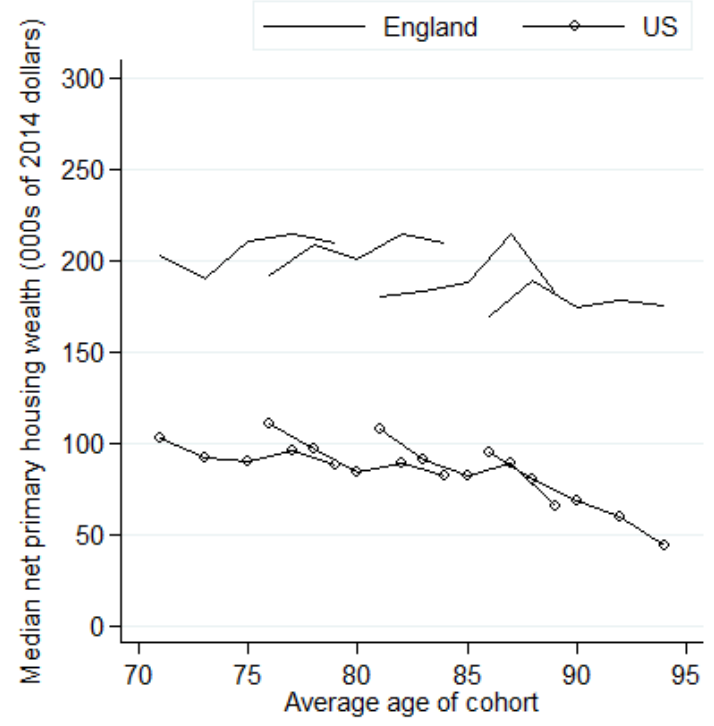

Notes: The 'balanced' sample includes only households where at least one member was still alive and responding to ELSA/HRS at the end of our panel in 2010/11.

It should be noted though that changes in housing wealth are not the only source of difference between the U.S. and England. While median net nonprimary housing wealth declines with age among English households, it declines much more sharply in the U.S. For example, among households born in 1929-33 (the leftmost line in the right-hand panel of Figure 6), in the U.S. median nonhousing wealth fell by 44 percent during the eight years, compared to a fall of 24 percent in England. (To aid interpretation, recall that the average life expectancy in the U.S. of someone aged 70-74 in 2000-2009 was 15 years). 
However, the initial level of net nonhousing wealth is lower in England than the U.S. This lower initial level could matter for the decumulation trajectory if, for example, households want to die with sufficient wealth to finance funeral expenses. Indeed, when we divide English households into tertiles according to their total net wealth we do find that net nonhousing wealth declines sharply for the richest households (among whom median nonhousing wealth is slightly higher than the median across all U.S. households). For example, among the richest English households born in 1929-33, median nonhousing wealth was around £113,000 in 2002/03 and declined by 35 percent by 2010/11.

In summary then, we find that U.S. households gradually reduce their net wealth through retirement, whereas English households actually accumulate wealth. This accumulation is driven by increases in primary housing wealth, which offset the slow decumulation of nonhousing wealth over the period we consider. Leaving housing wealth to one side, English households reduce their nonhousing assets less rapidly than their U.S. counterparts. However, levels of nonhousing wealth are generally higher in the U.S. than in England, and remain so on average despite the faster rate of drawdown. This finding of slower wealth drawdown in England is surprising, given that life expectancies among these households are similar, and real incomes at older ages are on average declining in the U.S. but increasing in England.

\section{Potential explanations of the cross-country differences}

How might we explain the different asset trajectories in the U.S. and England, given that the starting level of assets and life expectancies are similar? A natural place to start is with the extensions to the simple life-cycle model purported by the existing literature to explain why households (particularly in the US) do not run down their wealth. Here we consider three such extensions: bequest motives, medical expense risk, and housing.

\section{Bequest motives}

Bequest motives have found empirical support in the U.S. in recent years, since they help to explain the distribution of wealth (De Nardi (2004)), lifetime savings, and wealth profiles (Love, Palumbo, and Smith (2009), and demand for life insurance products and annuities (Bernheim (1991)). While early papers from Hurd $(1987,1989)$ found no evidence of a meaningful bequest motive, more recently Kopczuk and Lupton (2007) use a more flexible strategy to estimate that around threequarters of elderly U.S. households have a bequest motive. Somewhat more simply, Laitner and Juster (1996) found that half of their sample of moderately high-income elderly households self-reported that leaving an estate is important.

This all suggests that bequest motives could have a role to play in explaining asset trajectories in later life. Of course in practice, as shown by Dynan, Skinner, and Zeldes (2002), bequest motives and precautionary motives for saving are often overlapping, and cannot generally be distinguished. This 
helps explain why in some contexts (for example, De Nardi, French, and Jones (2010)) the addition of a bequest motive appears to be of little benefit to explaining observed asset trajectories.

There has been less literature on bequest motives in England (Inkmann and Michaelides (2012) is one exception). However, such motivations are likely to be important for explaining the low drawdown of wealth in retirement. When asked (as part of the Wealth and Assets Survey) to selfreport the importance of 'leaving property or money as an inheritance,' more than 70 percent of older households (where either the response person or their partner were age 70 or older) had at least one individual reporting that this was 'very important' or 'fairly important' to them (with the remainder reporting 'not very important,' 'not at all important,' or 'no opinion'). This compares to around 50 percent of similarly aged U.S. households interviewed by the Survey of Consumer Finances in 2007 who reported that it was 'very important' or 'important' to 'leave an estate or inheritance to their surviving heirs,' with a further 20 percent reporting that it was 'somewhat important' (the remainder reporting that it was 'not important' or that their opinions differed to those of their partner).

To our knowledge there has been no more detailed comparison of the prevalence or size of bequest motives between the U.S. and England. Therefore, the extent to which different bequest motives could explain the different asset trajectories in the U.S. and England remains a topic for future research, but it seems unlikely it will provide a full explanation for the differences observed.

\section{Medical expense risk}

A second strand of the literature that seeks to explain why households do not run down their wealth in retirement has considered uncertain medical expenses. The impact of such expense risk on household savings in the U.S. was explored in an early study by Kotlikoff (1988), and subsequently by Hubbard, Skinner, and Zeldes (1994), Palumbo (1999), and Love, Palumbo, and Smith (2009) among others. The most relevant contribution is that of De Nardi, French, and Jones (2010), who estimate a structural model of life-cycle saving that incorporates heterogeneous medical expenses. They illustrate that, when medical expense risk is removed, older households would be expected to spend down their wealth much more rapidly. In other words, precautionary saving for medical expense risk is a key driver of the relatively slow decumulation of wealth among older U.S. households. ${ }^{2}$

To the extent that out-of-pocket medical spending risk is lower in England, the English have less of a motivation to save into old age. Thus the lower levels medical spending risk in England should,

\footnotetext{
${ }^{2}$ De Nardi, French, and Jones (2010) show that the impact of medical expense risk on asset trajectories for their specification without a bequest motive. Including a bequest motive likely dampens the apparent role of medical expenses. As Dynan, Skinner, and Zeldes (2002) point out, precautionary and bequest motives cannot generally be distinguished since wealth serves both purposes.
} 
if anything, lead to lower levels of wealth in early retirement, and to more rapid run down of wealth during retirement.

It is not completely clear how big are the differences in medical spending risk between England and the US. In England medical expenses are funded by the National Health Service (NHS), and so households arguably do not have the same precautionary incentive to save. However, not all healthrelated costs for English households are met by the NHS. In particular, the cost of long-term care needs ('social care') is not met by the NHS and must typically be privately funded, with only a small number of individuals with very severe needs and low assets being entitled to state funding (provided through their local authorities). These costs can be substantial - for example, in 2013/14 the average cost of a private sector nursing home per permanent resident was £729 per week (Curtis (2014)). Data from the Organisation for Economic Co-operation and Development (2005) suggests that total costs of long-term care for older people (and the fraction of this care that is privately funded) are similar in the U.S. and the U.K.

We have high quality data for out of pocket medical spending for the U.S. in the HRS data. Figure 9 describes, for U.S. households, average out-of-pocket expenditure on nursing home stays and average out-of-pocket expenditure on other health related items (including hospital, outpatient, doctor visits, dentist, prescription changes, home health care, and specialist facilities) as reported in the HRS. This clearly indicates that it is nursing home stays that are the main driver of health expenses at older ages. Out-of-pocket medical spending on items other than long-term care averages slightly more than $\$ 5,000$ per year, and does not change much with age (except for at older ages when the proportion of couple households declines). On the other hand, medical spending on long-term care is very low until age 80 , then rises rapidly to more than $\$ 15,000$ per year per person by age 100 . 
FIGURE 9

Average U.S. household long-term care costs and other medical expenses by age

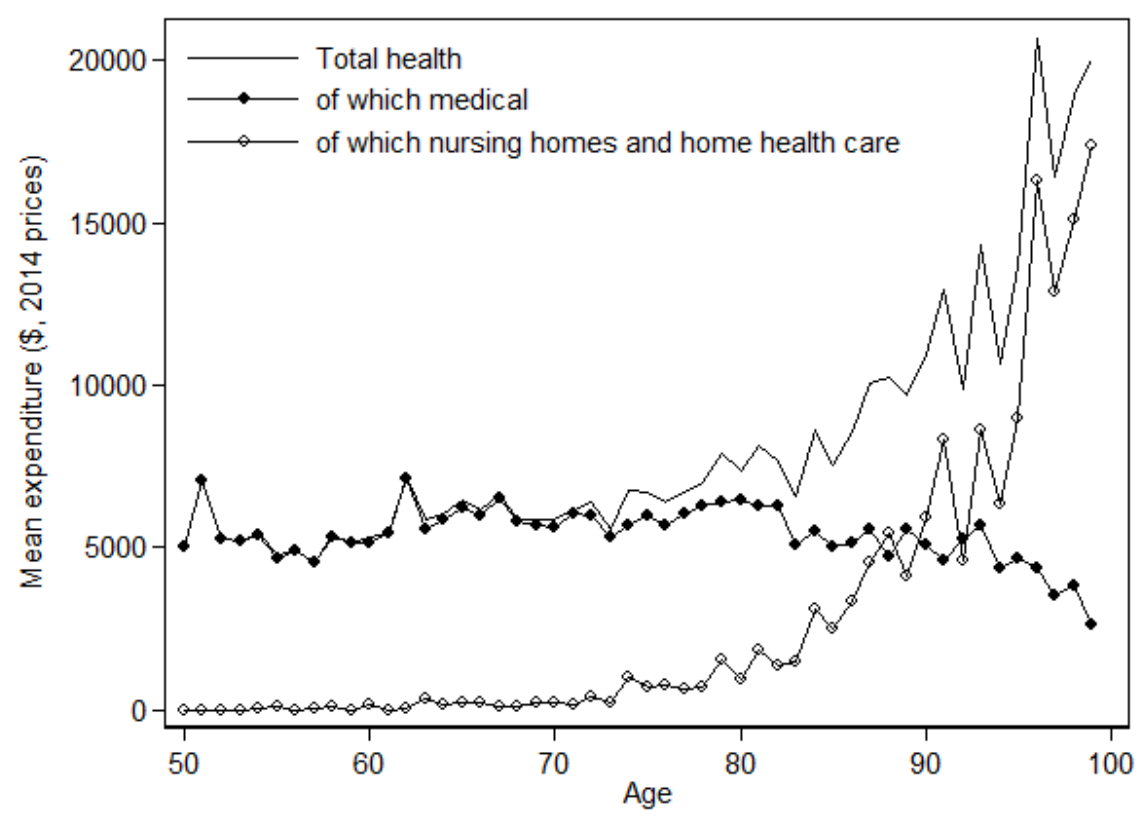

Notes: Pooled cross section of households in the HRS between 2002 and 2008 (inclusive).

This distinction - between health care and long-term care - is highlighted by Kopecky and Koreshkova (2014), who argue that variation in nursing home expense risk conditional on age (on top of the age-related variation in total health expenses) substantially slows down wealth decumulation at older ages in the U.S.

Because a large share of medical spending risk is from long-term care, and because English and American households potentially face similar risk of long-term care spending, the difference between the average level of health expenses faced by U.S. and English households may not be large. Unfortunately, there are currently no estimates of the risk of late life medical expenses in England comparable to those in the U.S. (for example, French and Jones (2004), Brown and Finkelstein (2008)), and therefore it is not possible to quantify the extent to which differences in observed asset trajectories may reflect different precautionary incentives to save in the two countries.

\section{Housing}

Housing is clearly an important proximate reason for the different wealth trajectories between the U.S. and England. The profile of net wealth for English households is driven by the trajectory of housing wealth, and the trajectory of net housing wealth is very different in England than the US, largely due to different movements in house prices. However, while this may be a proximate explanation for the run up in net housing wealth among English households, it begs the question why households did not subsequently draw on this wealth to fund consumption. 
One possible answer is that bequest motives may be tied to house prices. If older households are concerned with the utility of their heirs, and rising house prices increases the cost of that utility, then this may increase the amount that older households want to pass on and so constrain consumption out of wealth increases.

An alternative explanation is that housing is different from other assets. Housing is illiquid: It is difficult for the elderly to obtain mortgages especially in England. Reverse mortgages involve high costs and require a significant degree of financial literacy. Although the elderly can sell their homes and rent, selling a home involves financial and emotional transaction costs. Furthermore, homeownership itself may provide utility, for example through a sense of security or the ability to modify the home to one's tastes. Finally, there may be other financial benefits of homeownership relative to renting. For example, homeownership confers certain tax advantages, and homeowners need not be concerned with the risk of future rent changes. Extending the simple life-cycle model to include housing as a separate asset with these features could potentially result in predicted asset trajectories in retirement that exhibit little decumulation of housing wealth, and little response to housing wealth shocks.

Along exactly those lines, Nakajima and Telyukova (2012) estimate a life-cycle model with both housing and nonhousing wealth, in addition to medical expense risk and a bequest motive, to explore asset trajectories in retirement. In their model, housing yields a consumption flow (where individuals have a preference for living in their own home relative to renting a similarly expensive house) and borrowing against the home or moving home involves transaction costs. They find that wealth decumulation at older ages is slowed by the combination of households' utility from housing consumption and the constraints on borrowing against housing. Furthermore, they find that households would choose to reduce house maintenance (at the cost of declining equity values) if given the option - suggesting that households would choose to decumulate housing wealth if it were more liquid. In subsequent work, Nakajima and Telyukova (2013), demonstrate that if medical expense risk were lower, then asset decumulation would be predicted to be faster, but predominantly through faster decumulation of nonhousing assets. This suggests that housing is not acting as a precautionary asset.

These findings are in contrast to those of Skinner (1996), who tests multiple possible explanations for the lack of housing drawdown in retirement. He finds that the propensities to consume out of housing wealth among homeowners is larger among younger households than older households. He argues that this fact is most consistent with models that feature medical spending and income risk. If medical spending risk is important, then older households might be reluctant to reduce housing wealth, as housing wealth provides a valuable form of insurance. Davidoff (2015) also shows how home equity may substitute for formal long-term care insurance, though this could be the result of housing illiquidity as much as the driver behind households holding on to housing wealth.

However, the literature has far from reached consensus on the size of marginal propensities to consume out of housing wealth shocks - the evidence for Skinner's conclusions. While some studies 
in the U.K. have found large effects of housing wealth shocks on consumption (for example, Campbell and Cocco (2007)) others have not (for example, Disney et al. (2010), Banks et al. (2012)). Attanasio et al. (2009) argue that common causality has been the most important factor linking house prices and consumption. In good economic times, incomes, house prices, and consumption all rise. Thus it is not obvious if it is rising house prices or rising incomes that drive rising rising consumption.

A number of other studies have provided indicative evidence of a role for transaction costs in explaining the lack of drawdown of housing. Yang (2009) argues that housing transaction costs explain why housing consumption does not decline at older ages in the way that nonhousing consumption does. In a cross-country study, Chiuri and Jappelli (2010) find that rates of changing home ownership are related to an index of mortgage regulation. Venti and Wise (1991) for the US, and Hancock (1998) for the U.K., estimate the increase in household income that would be possible given mortgage equity withdrawal products, and suggest that for most households (particularly those in poverty) the gains would be small and so potentially not worth the transaction costs. Davidoff (2004) highlights that older households spend less on maintaining their homes, which could be interpreted as a 'transaction free' way of reducing housing equity (though, clearly, there are other potential explanations as well).

There is therefore much empirical evidence to suggest that the consumption value of housing and transaction costs associated with drawing on housing wealth could explain why this wealth is only slowly decumulated at older ages. This could then explain why the greater positive housing wealth shocks in England are not spent down, and therefore help explain the different asset profiles between England and the U.S.

However, a final point to note is that - even absent recent price changes - housing wealth is spent down less rapidly in England than in the US. This was shown in Figure 8, and appears largely due to lower prevalence of moving out of property ownership in England. The decline in the proportion of households with property wealth in England and the U.S. is shown in Table 4. If it is features of housing as an asset that are limiting housing drawdown (rather than precautionary saving or bequest motives), then there would need to be some difference in these features between the U.S. and England to explain the more limited drawdown of housing wealth in England. 
TABLE 4

Proportion of households with positive property wealth

\begin{tabular}{|c|c|c|c|c|c|c|}
\hline & \multicolumn{3}{|c|}{ US } & \multicolumn{3}{|c|}{ England } \\
\hline Age in 2002: & 2002 & 2010 & Change & 2002 & 2010 & Change \\
\hline $70-74$ & 0.84 & 0.79 & -0.05 & 0.81 & 0.76 & -0.05 \\
\hline $75-79$ & 0.82 & 0.68 & -0.13 & 0.78 & 0.74 & -0.04 \\
\hline $80-84$ & 0.74 & 0.62 & -0.12 & 0.71 & 0.63 & -0.08 \\
\hline $85-89$ & 0.70 & 0.57 & -0.13 & 0.67 & 0.60 & -0.08 \\
\hline All & 0.79 & 0.68 & -0.11 & 0.76 & 0.71 & -0.05 \\
\hline
\end{tabular}

Banks et al. (2010, 2012a) compare downsizing at older ages in the U.S. and Britain, and find that there is lower mobility among both owners and renters in England than in the US. They attribute this, in part to a greater prevalence of subsidised renters in Britain and to lower spatial variation in amenities such as climate in Britain. They also report that mobility is lower at all ages in England than the US; if older households in England have been in their house and neighbourhood for longer, and have moved less frequently throughout their lives, then the emotional costs of moving may be greater than for their U.S. counterparts.

There are also institutional differences between mortgage markets in the U.S. and England which may affect mobility. The U.S. mortgage market is dominated by long-term fixed rate mortgages (normally for 15 or 30 years), while in the U.K. mortgages are generally variable rate, with only short term (two to five year) fixed rate mortgages typically available. In the U.S., federal law bars credit discrimination on the basis of age and so age is not a factor in conventional mortgage approvals. In contrast, in England most lenders have maximum ages to which conventional mortgages can run typically 70-75. This likely explains most of the difference in the prevalence of housing-related debts at older ages. While Banks et al. (2010, 2012a) point to financial transaction costs as being a possible explanation for the differences in housing mobility observed, there is an absence of literature that quantifies the difference in transaction costs or the implications that these, therefore, have for household behaviour. This would be another interesting avenue for research.

Finally, there are also differences between equity release products available in the U.S. and England. In the U.S. there is a government administered Home Equity Conversion Mortgage (HECM), which accounts for around 90 percent of the market, and which Davidoff (2014) argues offers a favorably priced product. In contrast in England, there are a variety of equity withdrawal products available, from a number of providers (though the market is concentrated, see Towers Watson (2013)). This extra choice may be expected to provide greater flexibility and therefore increase demand. On the other hand, the array of choice and providers may make it harder for individuals to understand and engage with the market, and the lack of government involvement may mean that the products that are available are less favorably priced than those in the U.S. Take up of equity release products in both the U.S. and England is still low. For example, in the U.S. the proportion of home owners with reverse mortgages increased from under 0.5 percent in 2005 to 
slightly more than two percent in 2011 (Nakajima and Telyukova (2014)). Institutional differences in equity release products is therefore unlikely to be the main driving force behind the lower housing wealth decumulation in England.

To summarise, our empirical facts suggest that the nature of housing as an asset has an important impact on wealth trajectories at older ages. In England, where more rapid house price increases were experienced over the first half of the 2000s than in the US, this resulted in rapid increases in net housing wealth that was not drawn on to fund consumption. Because housing is such a large proportion of household wealth in England, this drove the profile of total net assets. We are not able to unpick from our results which aspect or aspects of housing - its consumption value, transaction costs, or the risk-return mix - mean that it is not drawn on in retirement. However, our empirical facts suggest that one or more of these are more pertinent in England, where households are less likely to move and draw on their housing wealth, than in the US.

\section{Conclusions}

In this paper we use comparable panel data from the HRS and ELSA to provide the first detailed comparison of asset trajectories for U.S. and English retiree households. Life expectancies, median asset levels, and median incomes at ages 70-74 are similar in the two countries, though real incomes tend to rise in England and fall in the US. All else equal, a simple life-cycle model would therefore suggest English retirees would decumulate wealth faster than their U.S. counterparts.

Contrary to this, we find that assets are drawn down more slowly in England than in the US. In fact, median net wealth of English retirees actually increased between 2002 and 2010 - proximately due to the more rapid growth in house prices in England than the U.S. during this period.

Why do English retirees drawdown their wealth less quickly? There may be differences in bequest motives and precautionary saving for medical expenses. These are the explanations that have gained most traction in rationalising the observed asset trajectories in the US. Important avenues for future research will be exploring whether bequest motives do differ, and estimating late life health expense risk in England, where the presence of the NHS, which insures medical expense risk, makes the institutional environment very different to that in the U.S.

However, housing looks likely to be the most important source of the difference in observed asset profiles. We show that house prices rose more rapidly in England than the U.S. during our sample period. If households are unable or unwilling to draw on housing in retirement, then this would explain why English households chose not to decumulate their housing wealth gains during retirement. Further research is required to identify whether it is the consumption value of housing, the financial and emotional transaction costs involved in releasing housing wealth, the risk-return mix provided by housing, or some combination of these that means that households do not draw on their housing wealth. However, our results do suggest that these effects are stronger in England than in the 
US, since English households are less likely to move out of owning property at older ages than U.S. households.

In this paper we have presented the empirical facts on the comparison between wealth decumulation in the U.S. and England. An important next step would be to construct a life-cycle model that could explain the observed asset trajectories in the two countries. Our results suggest that the inclusion of bequest motives, the risk of health expenses, and housing as a distinct asset would all be important.

\section{References}

Attanasio, O. P., Blow, L., Hamilton, R., \& Leicester, A. (2009). Booms and busts: Consumption, house prices and expectations. Economica, 76(301), pp. 20-50.

Banks, J., Blundell, R., Oldfield, Z., \& Smith, J. P. (2010). Housing price volatility and downsizing in later life. In Research findings in the economics of aging (pp. 337-379). University of Chicago Press.

Banks, J., Blundell, R., Oldfield, Z., \& Smith, J. P. (2012a). Housing mobility and downsizing at older ages in Britain and the USA. Economica, 79(313), pp. 1-26.

Banks, J., Crawford, R., Crossley, T., \& Emmerson, C. (2012b). The effect of the financial crisis on older households in England. IFS Working Papers, W12/09.

Bernheim, B. D. (1992). How strong are bequest motives? Evidence based on estimates of the demand for life insurance and annuities. Journal of Political Economy, 99(5), pp. 899-927.

Brown,J. and Finkelstein, A. (2008). The Interaction of Public and Private Insurance: Medicaid and the LongTerm Care Insurance Market. American Economic Review, 98(3), pp. 1083-1102.

Campbell, J. Y., \& Cocco, J. F. (2007). How do house prices affect consumption? Evidence from micro data. Journal of Monetary Economics, 54(3), pp. 591-621.

Chiuri, M. C., \& Jappelli, T. (2010). Do the elderly reduce housing equity? An international comparison. Journal of Population Economics, 23(2), pp. 643-663.

Curtis, L (2014). Unit Costs of Health and Social Care. Personal Social Services Research Unit, University of Kent.

Crimmins, E., Preston, S. \& Cohen, B. (eds) (2011). National Research Council (US) Panel on Understanding Divergent Trends in Longevity in High-Income Countries: Explaining Divergent Levels of Longevity in High-Income Countries. National Academies Press.

Davidoff, T. (2004). Maintenance and the Home Equity of the Elderly. Fisher Center for Real Estate and Urban Economics Paper, (03-288).

Davidoff, T. (2015). Can "High Costs” Justify Weak Demand for the Home Equity Conversion Mortgage?. Review of Financial Studies, forthcoming.

De Nardi, M. (2004). Wealth inequality and intergenerational links. The Review of Economic Studies, 71(3), pp. 743-768.

De Nardi, M., French, E. \& Jones, J.B. (2010). Why Do the Elderly Save? The Role of Medical Expenses. Journal of Political Economy, 118(1), pp 39-75.

De Nardi, M., French, E. \& Jones, J.B. (2015). Savings After Retirement: A Survey. NBER working paper no. 21268.

Disney, R., Gathergood, J., \& Henley, A. (2010). House price shocks, negative equity, and household consumption in the United Kingdom. Journal of the European Economic Association, 8(6), pp. 1179-1207.

Dynan, K. E., Skinner, J., \& Zeldes, S. P. (2002). The importance of bequests and life-cycle saving in capital accumulation: A new answer. American Economic Review, 92(2), pp. 274-27. 
Freenberg, D.R. \& Coutts, E. (1993). An Introduction to the TAXSIM Model. Journal of Policy Analysis and Management, 12(1), pp. 189-194.

French, E. \& Jones, J.B. (2004). On the Distribution and Dynamics of Health Care Costs. Journal of Applied Econometrics, 19(4), pp. 705-721.

French, E., De Nardi, M., Jones, J.B., Baker, O. \& Doctor, P. (2006). Right before the end: Asset decumulation at the end of life. Federal Reserve Bank of Chicago Economic Perspectives, Third Quarter 2006, pp.2-13.

Hancock, R. (1998). Housing wealth, income and financial wealth of older people in Britain. Ageing and Society, 18(01), pp. 5-33.

Hubbard, R. G., Skinner, J., \& Zeldes, S. P. (1994). Expanding the life-cycle model: Precautionary saving and public policy. The American Economic Review, 84(2), pp. 174-179.

Hurd, M. D. (1987). Savings of the elderly and desired bequests. The American Economic Review, 77(3), pp. 298-312.

Hurd, M. D. (1989). Mortality risk and bequests. Econometrica, 57(4), pp. 779-813.

Inkmann, J., \& Michaelides, A. (2012). Can the life insurance market provide evidence for a bequest motive?. Journal of Risk and Insurance, 79(3), pp. 671-695.

Kopczuk, W., \& Lupton, J. P. (2007). To leave or not to leave: The distribution of bequest motives. The Review of Economic Studies, 74(1), pp. 207-235.

Kopecky, K. \& Koreshkova, T. (2014). The Impact of Medical and Nursing Home Expenses on Savings. American Economic Journal: Macroeconomics, 6(3), pp. 29-72.

Kotlikoff, L. J. (1989). Health Expenditures and Precautionary Saving. in Kotlikoff, L.J. What Determines Saving? MIT Press, Cambridge, MA.

Laitner, J., \& Juster, F. T. (1996). New evidence on altruism: A study of TIAA-CREF retirees. The American Economic Review, 86(4), pp. 893-908.

Love, D. A., Palumbo, M. G., \& Smith, P. A. (2009). The trajectory of wealth in retirement. Journal of Public Economics, 93(1), pp. 191-208.

Nakajima, M., \& Telyukova, I. (2012). Home equity in retirement. Networks Financial Institute Working Paper No. 2011-WP-08B.

Nakajima, M., \& Telyukova, I. (2013). Housing in retirement across countries. Boston College Center for Retirement Research Working Paper, (2013-18).

Nakajima, M., \& Telyukova, I. (2014). Reverse mortgage loans: A quantitative analysis. FRB of Philadelphia Working Paper No. 14-27

Palumbo, M. G. (1999). Uncertain medical expenses and precautionary saving near the end of the life cycle. The Review of Economic Studies, 66(2), pp. 395-421.

Rohwedder, S., Hurd, M., Pantoja, P. \& St Claire, P. (2005). Tax Calculations for HRS 2000 \& 2002 Documentation, RAND.

Skinner, J. S. (1996). Is housing wealth a sideshow?. in Wise, D. (ed) Advances in the Economics of Aging, pp. 241-272. University of Chicago Press.

Towers Watson (2013).Equity release: accessing housing wealth in retirement. London.

Venti, S. F., \& Wise, D. A. (1991). Aging and the income value of housing wealth. Journal of Public Economics, 44(3), 371-397.

Wolff, E. (2004). Changes in household wealth in the 1980s and 1990s in the U.S. Levy Economics Institute Working Paper No. 407.

Yang, F. (2009). Consumption over the life cycle: How different is housing?. Review of Economic Dynamics, 12(3), 423-443. 